\title{
MENANAMKAN NILAI-NILAI KESEJARAHAN DALAM PEMBELAJARAN SEJARAH MELALUI PUISI KEPAHLAWAN
}

\author{
Ateng Rasihudin ${ }^{1}$ \\ Guru SMA Negeri 2 Karawang \\ Jalan Manunggal, Plumbon Sari, Lamaran, Karawang Timur, Palumbonsari, Karawang Tim., \\ Kabupaten Karawang, Jawa Barat 41314
}

\begin{abstract}
ABSTRAK
Menanamkan nilai-nilai kesejarahan (internalisasi) dapat dikembangkan oleh guru sejarah melalui pembacaan puisi kepahlawanan, karena proses pembacaan puisi kepahlawanan mampu membentuk suasana dan penjiwaan pada sipembaca dan pendengarnya sehingga akan mampu memberi pesan nilai yang mendalam bagi siswa. Penelitian ini merupakan Penelitian Tindakan Kelas dengan pendekatan kualitatif. Teknik pengumpulan data yang digunakan dalam penelitian ini adalah: observasi, catatan lapangan, dokumentasi, dan wawancara. Sumber data adalah siswa kelas XI IPS-1. Penelitian ini dilaksanakan dalam empat siklus dengan tujuh kali tindakan. Temuan dalam penelitian tindakan kelas ini adalah bahwa dengan melalui pembacaan puisi kepahlawanan dalam pembelajaran sejarah dapat menanamkan nilai-nilai kesejarahan siswa, melalui tahap transfer nilai, transaksi nilai, dan trans internalisasi nilai sehingga terjadi pembentukan kepribadian dan watak siswa yang mapan. Hal ini dapat terlihat dari hasil observasi dan wawancara dalam empat siklus yang dilaksanakan.
\end{abstract}

\section{Kata Kunci: internalisasi nilai, puisi kepahlawanan, transfer nilai, transaksi nilai, trans internalisasi nilai}

\begin{abstract}
Instilling historical values (internalization) can be developed by history teachers through reading poetry of heroism, because the process of reading heroic poetry is able to shape the atmosphere and inspiration of readers and listeners so that they will be able to give a deep message of value to students. This research is a Classroom Action Research with a qualitative approach. Data collection techniques used in this study were: observation, field notes, documentation, and interviews. The data source is students of class XI IPS-1. This research was conducted in four cycles with seven actions. The findings in this classroom action research are that through reading poetry of heroism in history learning can instill students' historical values, through the stages of value transfer, value transactions, and trans value internalization so that the formation of established student personality and character is formed. This can be seen from the results of observations and interviews in four cycles carried out.
\end{abstract}

Keywords: value internalization, heroic poetry, value transfer, value transactions, trans value internalization

\section{PENDAHULUAN}

Belajar sejarah bukanlah hanya mempelajari pengetahuan masa lalu saja, yang terpenting dari itu adalah menjadikan sejarah sebagai pedoman bagi kehidupan sebagai manusia maupun sebagai warga negara. Seperti yang diungkapkan oleh Cicero "Historia Vitae Magistra" Sejarah adalah guru kehidupan. Upaya yang lebih utama dalam mempelajari

\footnotetext{
${ }^{1}$ Penulis Koresponden

E-mail address: atengrasihudin@gmail.com doi: $10.25157 /$ ja.v6i1.2045
}

sejarah adalah tranfer nilai-nilai sejarah, yang merupakan inti penting yang menjadikan sejarah sebagai "guru" kehidupan. Nilai-nilai yang terkandung dalam setiap peristiwa sejarah harus diwariskan pada generasi muda.

Mata pelajaran Sejarah memiliki arti strategis dalam pembentukan watak dan peradaban bangsa yang bermartabat serta dalam pembentukan manusia Indonesia yang memiliki

Copyright@2019 Jurnal Artefak e-ISSN: 2580-0027 
rasa kebangsaan dan cinta tanah air. Materi sejarah:

1. Mengandung nilai-nilai kepahlawanan, keteladanan, kepeloporan, patriotisme, nasionalisme, dan semangat pantang menyerah yang mendasari proses pembentukan watak dan kepribadian peserta didik;

2. Memuat khasanah mengenai peradaban bangsa-bangsa, termasuk peradaban bangsa Indonesia. Materi tersebut merupakan bahan pendidikan yang mendasar bagi proses pembentukan dan penciptaan peradaban bangsa Indonesia di masa depan;

3. Menanamkan kesadaran persatuan dan persaudaraan serta solidaritas untuk menjadi perekat bangsa dalam menghadapi ancaman disintegrasi bangsa;

4. Sarat dengan ajaran moral dan kearifan yang berguna dalam mengatasi krisis multidimensi yang dihadapi dalam kehidupan sehari-hari;

5. Berguna untuk menanamkan dan mengembangkan sikap bertanggung jawab dalam memelihara keseimbangan dan kelestarian lingkungan hidup.

Menurut filsafat Perenialisme, sasaran yang harus dicapai oleh pendidikan adalah kepemilikan atas prinsip-prinsip tentang kenyataan, kebenaran dan nilai yang abadi, serta tidak terikat oleh ruang dan waktu. Dalam pandangan ini, kurikulum akan menjadi sangat ideologis karena dengan pandangan perernialisme menjadikan peserta didik sebagai warga negara yang memiliki pengetahuan, keterampilan dan sikap yang diinginkan oleh negara. Pandangan perenialis lebih menekankan pada transfer of culture, seperti dalam kurikulum IPS yang bertujuan pada pembangunan jati diri bangsa pada peserta didik, yang menuju tercapainya integrasi bangsa (Nana Supriatna, 2007: 31).

Dengan demikian sejarah memiliki peran strategis bagi bangsa Indonesia dalam rangka membentuk pribadi-pribadi peserta didik sebagai generasi muda bangsa yang mewarisi nilai-nilai luhur kepahlawanan sebagai landasan terbentuknya rasa nasionalisme.

\section{METODE PENELITIAN}

\section{Metode Penelitian}

Metode penelitian yang akan digunakan dalam penelitian ini adalah Penelitian Tindakan Kelas (PTK) dengan pendekatan kualitatif.
Pemilihan metode Penelitian Tindakan Kelas dalam upaya menanamkan nilai-nilai kesejarahan melalui pembacaan puisi kepahlawanan, didasarkan pada alasan bahwa; Penelitian Tindakan Kelas mempunyai fungsi aplikatif bagi guru dalam menjalankan tugasnya dan dalam usaha meningkatkan kemampuan atau kompetensi guru dalam proses pembelajaran. PTK ini tidak hanya memberikan saran bagi guru tapi juga solusi. Sehingga dengan penelitian ini peneliti sebagai guru mendapatkan masukan dan sekaligus pedoman dalam menjalankan tugas sebagai guru sejarah yang inovatif dan kreatif. Sehingga berbagai persoalan dan pandangan keliru terhadap pelajaran sejarah dapat ditepis dan diantisipasi dengan menunjukkan buktibukti nyata akan pentingnya pembelajaran sejarah di sekolah melalui peranannya dalam menanamkan nilai-nilai sejarah dalam kehidupan sebagai bangsa Indonesia

Model yang diacu dalam penelitian ini adalah model yang dikembangkan oleh Kemmis \& Taggart ( Harianti, 2010: 15) yang terdiri dari: planning (perencanaan), acting \& observing (pelaksanaa dan pengamatan), serta reflecting (refleksi). Sedangkan siklus yang direncanakan meliputi beberapa siklus sesuai dengan kebutuhan dan tingkat keberhasilan yang dianggap cukup serta disesuaikan dengan batas waktu penelitian.

\section{Subjek, Guru Mitra (Kolaborator) dan Lokasi Penelitian \\ 1. Subjek Penelitian}

Subjek dalam penelitan ini adalah siswa kelas XI IPS-1 Semester Genap SMA Negeri 2 Karawang Tahun Pelajaran 2015/2016 dengan jumlah siswa 40 orang. Kelas ini merupakan salah satu kelas dari lima kelas program IPS di SMA Negeri 2 Karawang.

\section{Guru Mitra}

Guru mitra dalam PTK yang dilaksanakan peneliti bernama Wiwi Juwita,S.Pd. lahir di Karawang pada tanggal 16 Agustus 1964 dan telah berpengalaman mengajar di SMA Negeri 2 Karawang selama 30 tahun.

\section{Lokasi}

Lokasi penelitian tindakan kelas ini diselenggarakan di SMA Negeri 2 Karawang yang beralamat di Jalan Manunggal VII Palumbonsari Karawang, yang teletak di Kelurahan Paumbonsari, Kecamatan Karawang Timur, Kabupaten Karawang. 


\section{Waktu}

Penelitian ini dilaksanakan selama 3 bulan mulai bulan Januari sampai bulan Maret 2016. Kegiatan penelitian meliputi perencanaan (Planning), pelaksanaan (Actuating), dan pelaporan (Reporting).

\section{Lama Tindakan}

Penelitian Tindakan Kelas yang dilaksanakan peneliti dalam upaya penanaman nilai-nilai kesejarahan melalui pembacaan puisi kepahlawanan dalam pembelajaran sejarah, memerlukan waktu yang cukup lama. Hal ini dikarenakan proses menanamkan nilai atau internalisasi, tidak bisa nampak dalam waktu singkat. Internalisasi merupakan suatu proses panjang untuk sampai kepada suatu pembudayaan, dengan demikian perlu dikembangkan secara terus menerus dalam waktu yang cukup lama, demikian juga tindakan yang harus dilakukan pun memerlukan waktu lama juga.

Lama tindakan dalam penelitian ini akan ditentukan oleh tingkat keberhasilan dalam pelaksanaan untuk memperoleh data yang cukup lengkap dan peneliti telah memperoleh data yang memuaskan atau sampai pada tahap jenuh atau saturasi. Artinya penelitian ini akan berakhir jika telah terpenuhi data mengenai indikator yang menunjukkan siswa memiliki sikap dan nilai yang terimplikasi pada ucapan dan perbuatannya dalam kehidupan sehari-hari di lingkungan sekolah. Peneliti merencanakan tindakan kurang lebih selama empat bulan pelaksanaan pembelajaran, mulai bulan Januari hingga bulan April 2016.

\section{Analisis, Validasi dan Interpretasi Data \\ 1. Teknik Pengumpulan Data}

Penelitian Tindakan Kelas (PTK), sebagai penelitian yang bertradisi kualitatif memiliki karakteristik yang khas yang berkaitan dengan peran peneliti. Creswell (2010: 261) menyatakan bahwa salah satu karakteristik penelitian kualitatif adalah peneliti sebagai instrumen kunci (researcher as key instrument), dimana peneliti kualitatif mengumpulkan sendiri data melalui dokumentasi, observasi perilaku, atau wawancara dengan para partisipan. Dengan demikian peran peneliti dalam PTK ini merupakan instrumen utama dalam upaya mendapatkan data yang lengkap dan akurat.

Upaya untuk mendapatkan data yang lengkap dalam penelitian ini, diperlukan teknik dan instrumen yang tepat dan mampu memberikan data yang dibutuhkan. Adapun teknik pengumpulan data yang akan digunakan dalam Penelitian Tindakan Kelas ini adalah : Observasi, wawancara, tes, dokumentasi. Sedangkan instrumen penelitian yang digunakan adalah; catatan observasi, pedoman wawancara, dokumen tertulis, dan rekaman.

\section{Teknik Analisis Data}

Menurut Miles dan Huberman (1984 dalam Emzir, 2010: 129), ada tiga macam kegiatan dalam analisis data kualitatif, yaitu :

a. Reduksi Data

b. Model Data (Display Data)

Penarikan / Verifikasi Kesimpulan

\section{HASIL PENELITIAN DAN PEMBAHASAN}

\section{Hasil Penelitian}

\section{Perencanaan Pelaksanaan Siklus dan Tindakan}

Pelaksanaan penelitian ini direncanakan selama 3 bulan mulai bulan Januari sampai bulan Maret 2016. Kegiatan penelitian meliputi perencanaan (Planning), pelaksanaan (Actuating), dan pelaporan (Reporting).

Pelaksanaan penelitian ini dilakukan melalui empat siklus, yang diharapkan dengan treatment dalam empat siklus tersebut, terjadi improvement atau peningkatan dalam proses penanaman nilai-nilai pada diri siswa.

Pada siklus I sampai siklus III yang terdiri dari lima tindakan, proses pembelajaran dilakukan melalui pembacaan puisi oleh tiap kelompok dengan tujuan melihat bagaimana proses internalisasi nilai berlangsung. Sedangkan pada siklus IV yang terdiri dari dua tindakan dilakukan melalui wawancara dengan perwakilan tiap kelompok dengan harapan eksplorasi nilai-nilai yang terinternalisasi lebih lengkap dengan data yang cukup lengkap. 


\section{Hasil pelaksanaan pada Siklus I}

Berdasarkan observasi peneliti dan mitra selama siklus I ini, maka dapat disimpulkan dengan hasil sebagai berikut :

Tabel Hasil Observasi Siklus I

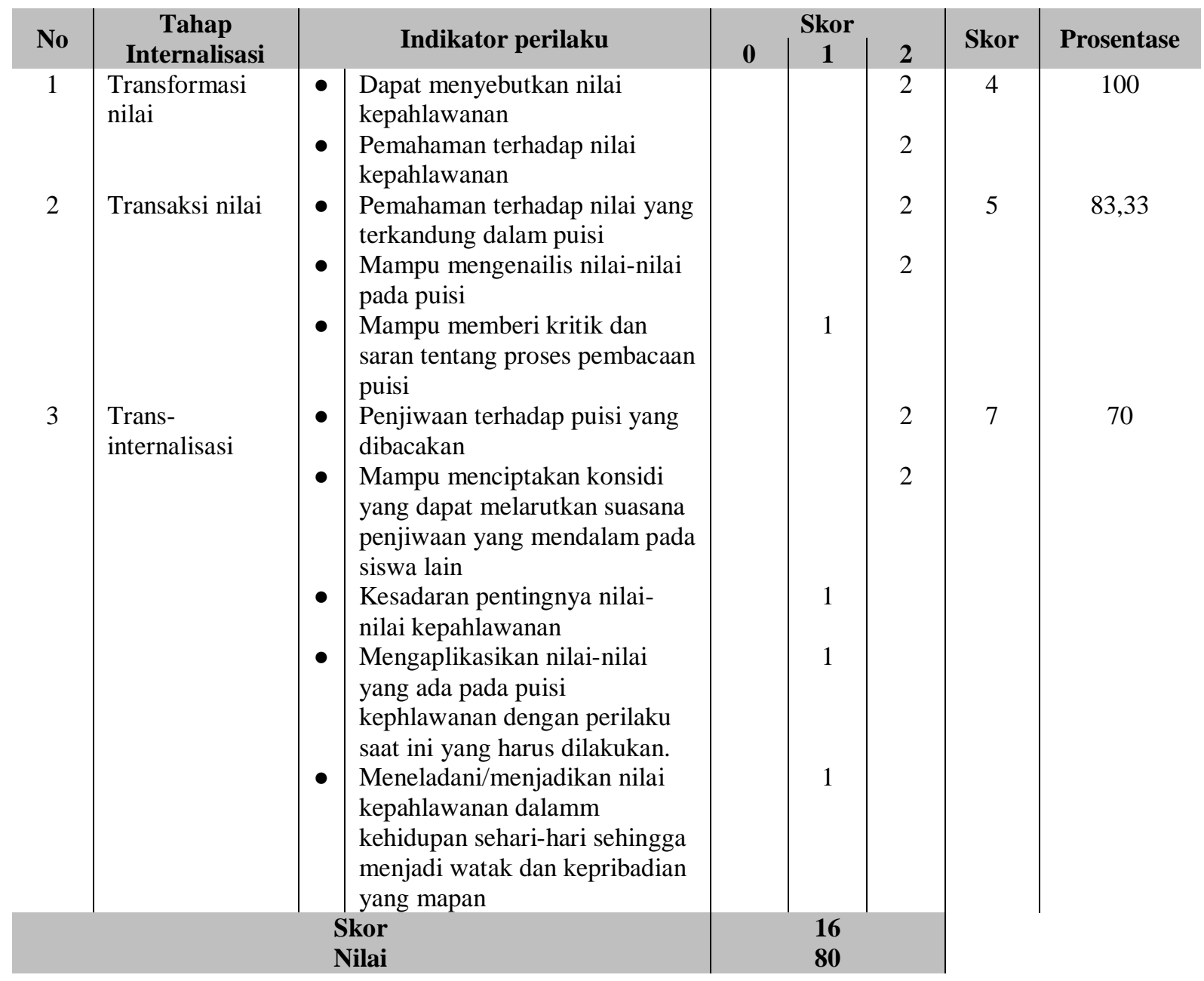

Bila dilihat perkembangan proses internalisasi nilai pada siklus i ini, transformasi nilai, transaksi nilai, dan trans internalisasi dapat dilihat dari diagram berikut :

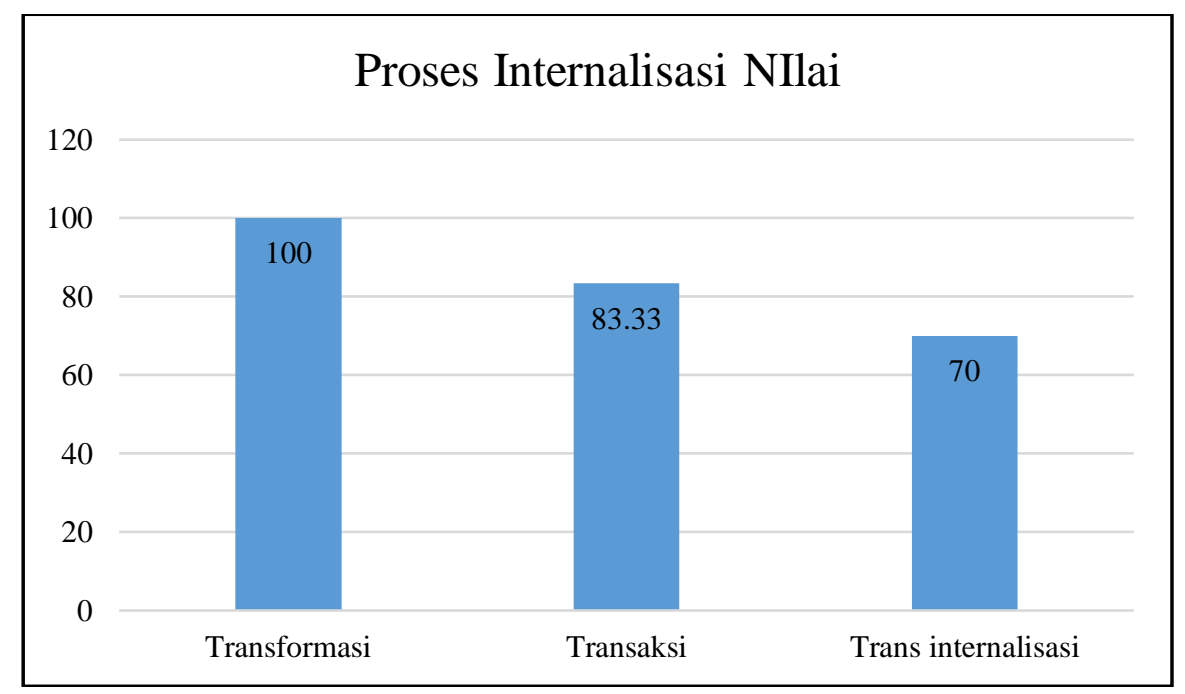




\section{Hasil pelaksanaan Siklus II}

Sisklus II dilaksanakan pada hari Kamis tanggal 18 Februari 2016, melalui satu kali tindakan deengan menampilkan tiga kelompok. Hal ini dilakuka oleh peneliti karena tindakan ini dilaksanakan pada hari kamis dengan jemlah jam pelajaran dua jam pelajaran, yaitu jam pertama dan kedua mulai pukul 07.00 sampai dengan 08.30.selama kurang lebih 90 menit, dengan pembagian waktu untuk satu kelompok masing-masing diberi waktu 30 menit. berikut :

Hasil onservasi peneliti dan mitra menyimpulkan pelaksanaan siklus II ini dengan data sebagai

Hasil Observasi Pada Siklus II

\begin{tabular}{|c|c|c|c|c|c|c|c|}
\hline No & Tahap Internalisasi & Indikator perilaku & 0 & kc & $?$ & Skor & Prosentase \\
\hline 1 & Transformasi nilai & \begin{tabular}{l|l} 
- & Dapat menyebutkan nilai \\
- & kepahlawanan \\
Pemahaman terhadap nilai \\
kepahlawanan
\end{tabular} & & & $\begin{array}{l}2 \\
2\end{array}$ & 4 & 100 \\
\hline 2 & Transaksi nilai & \begin{tabular}{l|l} 
- & Pemahaman terhadap nilai \\
- & Mang terkandung dalam puisi \\
- & Mada puisi \\
Mampu memberi kritik dan \\
saran tentang proses \\
pembacaan puisi
\end{tabular} & & 1 & 2 & 5 & 83,33 \\
\hline 3 & Trans-internalisasi & \begin{tabular}{l|l} 
- & Penjiwaan terhadap puisi yang \\
dibacakan \\
Mampu menciptakan konsidi \\
yang dapat melarutkan suasana \\
penjiwaan yang mendalam \\
- \\
- \\
Kesada siswa lain \\
nilai kepahlawan pentingnya nilai- \\
Mengaplikasikan nilai-nilai \\
yang ada pada puisi \\
kephlawanan dengan perilaku \\
saat ini yang harus dilakukan. \\
Meneladani/menjadikan nilai \\
kepahlawanan dalamm \\
kehidupan sehari-hari sehingga \\
menjadi watak dan kepribadian \\
yang mapan
\end{tabular} & & 1 & 2 & 8 & 80 \\
\hline & & Skor & \multicolumn{3}{|c|}{$\begin{array}{l}17 \\
85\end{array}$} & & \\
\hline
\end{tabular}

Jikla digambarkan dalam bentuk diagram, maka perkembangan proses internalisasi nilai pada siklus II ini dapat dilihat sebagai berikut

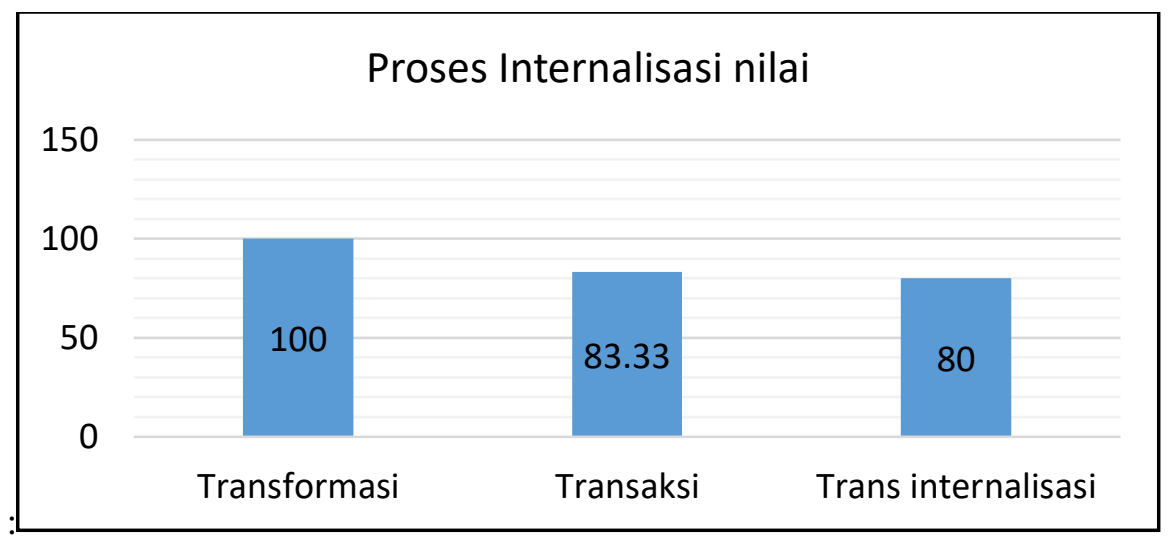




\section{Hasil pelaksanaan Siklus III}

Siklus III dilaksanakan melalui dua tindakan, yaitu tindakan ke-4 dan ke-5. Masing-masing tindakan dilaksanakan dua hari, yaitu hari Sabtu tanggal 20 Februari 2016 yang menampilkan satu kelompok penampil, dan hari Kamis tanggal 25 Februari 2016 yang terdiri dari dua kelompok penampil. Tujuan pelaksnaan siklus III sama dengan siklus sebelumnya yaitu terciptanya proses penanaman nilai atau internalisasi nilai-nilai kesejarahan pada siswa kelas XI IPS-1 melalui pembacaan puisi kepahlawanan.

Peneliti telah berkeyakinan bahwa penampilan dua kelompok terakhir ini mampu memberikan kepuasan pada peneliti, dan memberikan indikator telah tercapainya proses penanaman nilai kesejarahan pada puisi kepahlawanan. Namun walau demikian, peneliti masih ingin melengkapi data dan infromasi lebih kuat dan meyakinkan lagi. Oleh karena itu, peneliti dan observer sepakat untuk memberikan kelengkapan data dan informasi yang akurat lagi melalui wawancara pada siswa secara lebih terperinci, sehingga data apa yang belum muncul diharapkan akan tampil pada wawancara ini. Karena peneliti dapat memberikan pertanyaan yang membimbing siswa ke arah ungkapan yang diharapkan peneliti yang menjadi indikator tercapainya proses internalisasi nilai.

\section{Hasil Observasi Pada Siklus III}

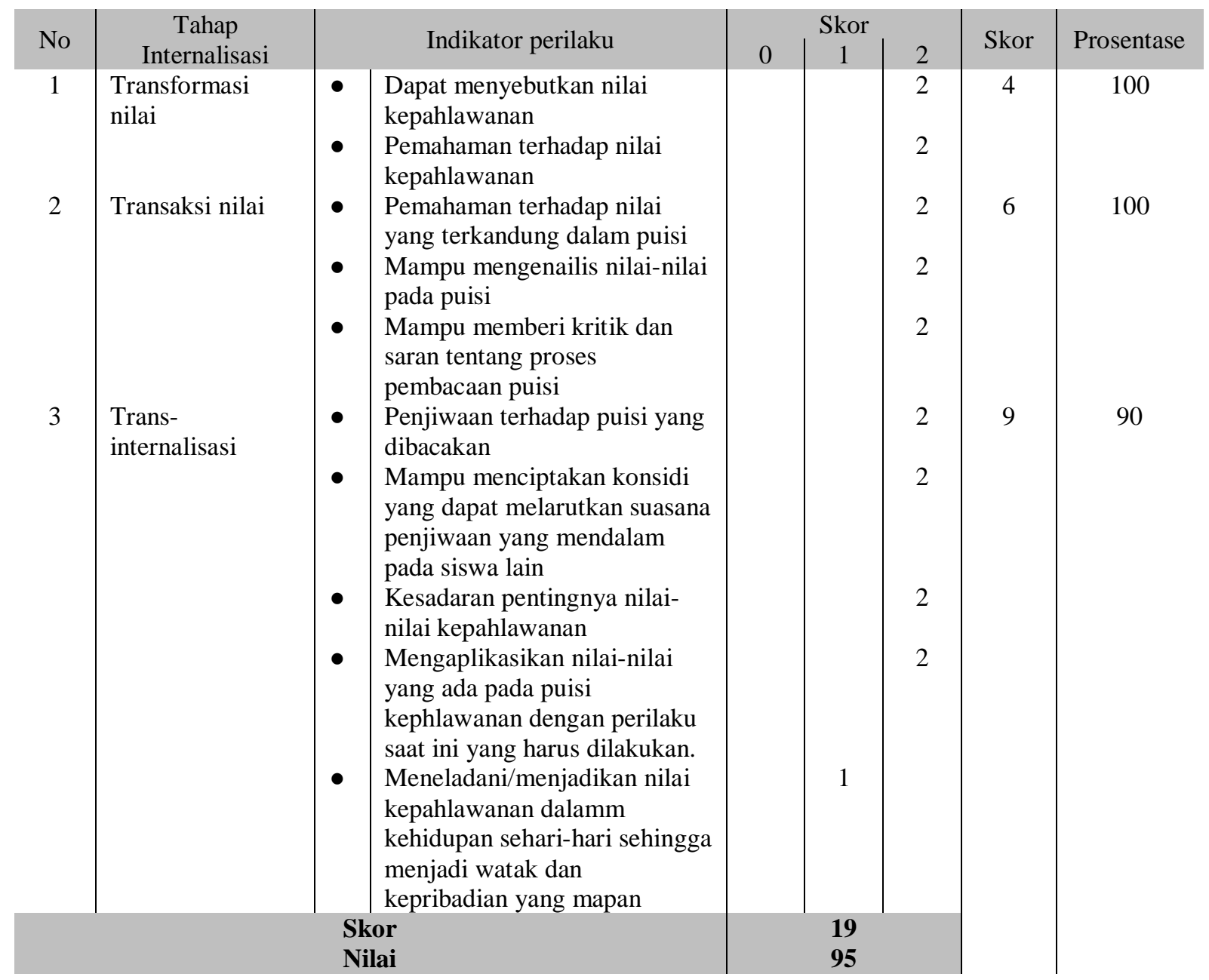


$\begin{array}{cccr}\text { Diagram } & \text { perkembangan } & \text { proses } \\ \text { internalisasi nilai pada siklus III dapat }\end{array}$ digambarkan sebagai berikut :

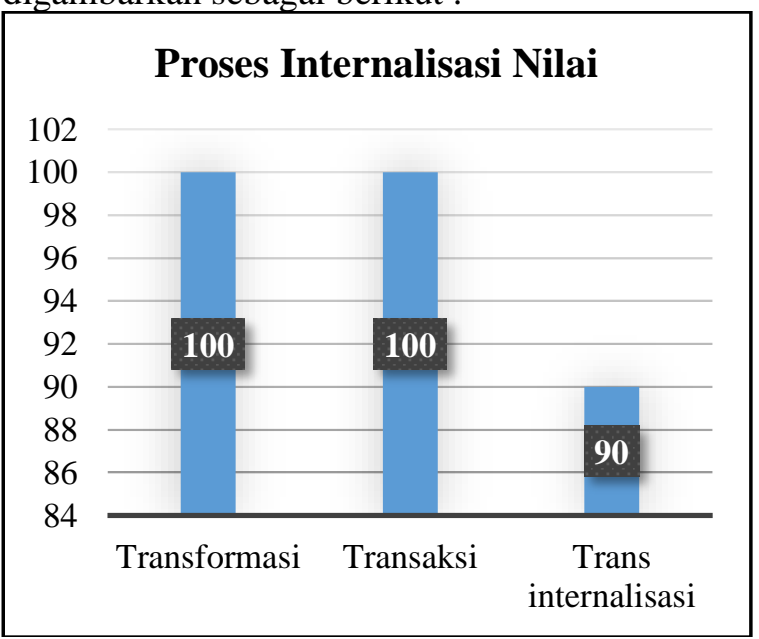

Jika kita bandingkan perkembangan proses internalisasi nilai dari siklus I hingga siklus III, baik yang berkaitan dengan tahap transformasi nilai, Transaksi nilai, dan Trans internalisasi, dapat disimpulkan dengan diagram sebagai berikut :
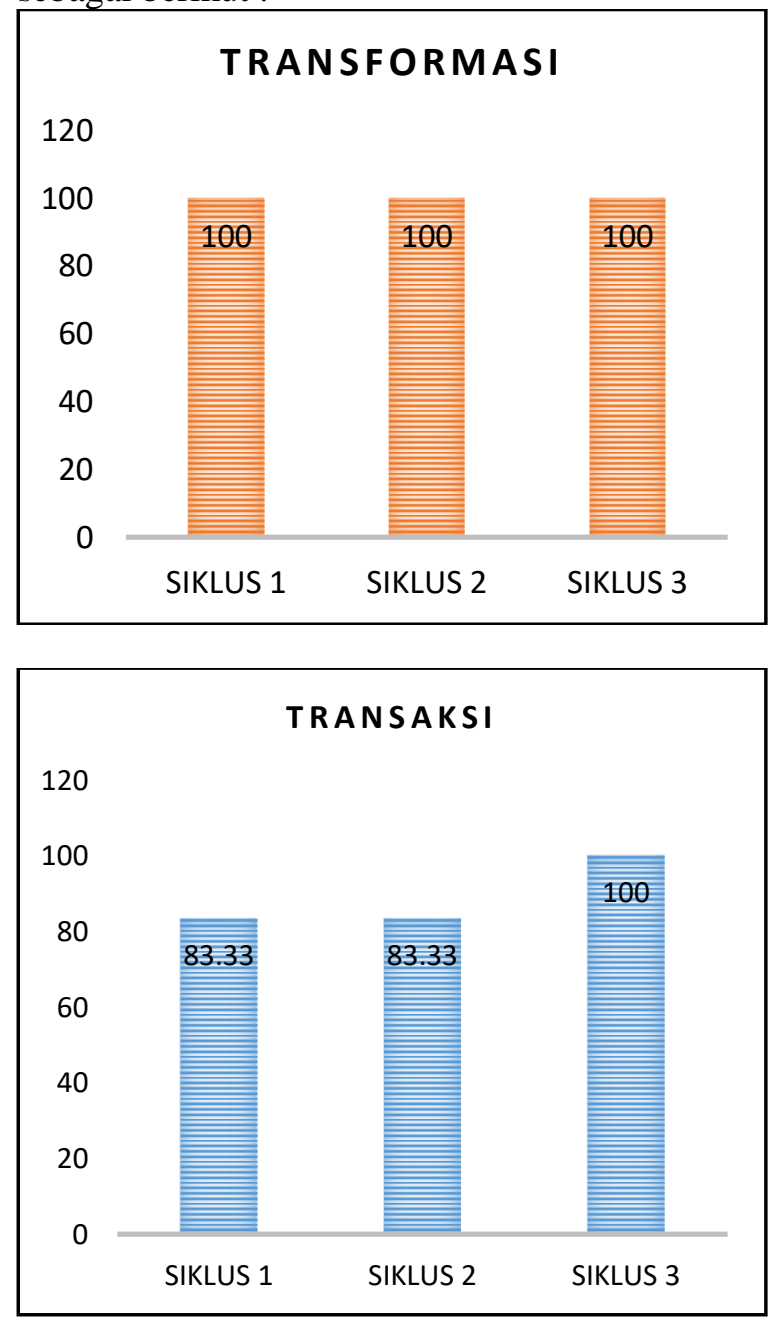

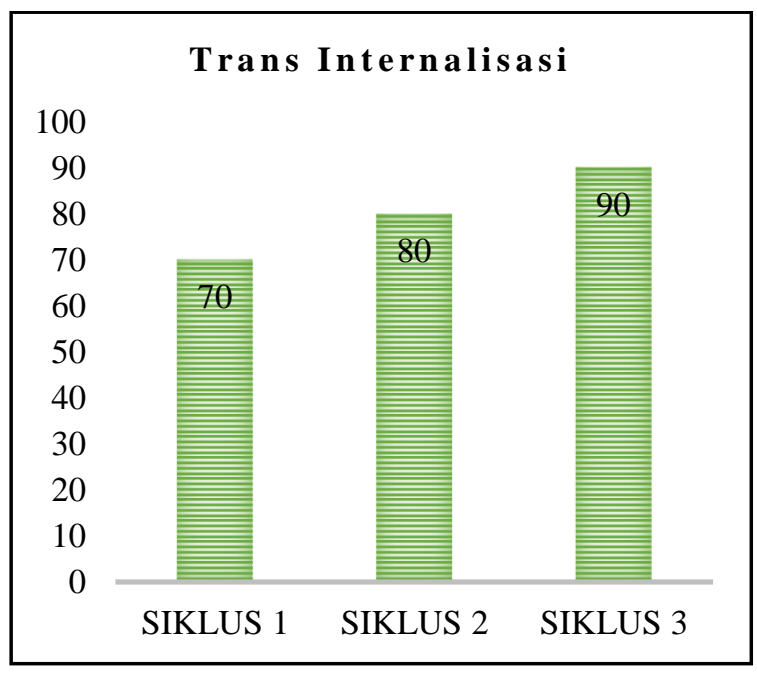

\section{Hasil pelaksanaan Siklus IV}

Siklus IV dilaksanakan sebagai upaya untuk meyakinkan telah tertanamnya nilai-nilai kepahlawanan terhadap siswa kelas XI IPS-1. Peneliti beranggapan bahwa proses internalisasi nilai ini telah terjadi pada siklus-siklus sebelumnya, namun perlu upaya untuk lebih menyakinkannya. Adapun upaya peneliti untuk mewujudkannya, perlu dilakukan wawancara khusus dengan siswa untuk mengeksplor dan menggali lebih dalam mengenai penanaman nilai ini.

Pelaksanaan siklus IV ini dilakukan dengan dua kali tindakan, yaitu tindakan ke-6 dilaksanakan hari Sabtu tanggal 26 Maret 2016, dan tindakan ke-7 yang dilaksanakan pada hari Kamis tanggal 31 Maret 2016. Untuk mendapatkan informasi lengkap tentang telah tercapainya internalisasi nilai tersebut, peneliti menggunakan instrumen wawacara terstruktur, sehingga dengan instrumen itu, peneliti dapat mengetahui sampai sejauh mana proses tindakan yang telah dilakukan mencapai tujuan yang diharapkan.

Adapun instrumen wawancarayang digunakan adalah sebagai berikut :

1. Apa yang kamu rasakan ketika puisi dibacakan?

2. Apakah pembacaan puisi kepahlawanan dapat menumbuhkan rasa kebangsaan ?

3. Nilai-nilai apa sajakah yang dapat kamu ambil dari puisi kepahlawanan?

4. Apakah sikap yang harus kamu tunjukkan sebagai hasil dari pembelajaran sejarah?

5. Apa yang kalian dapatkan dari pembelajaran sejarah dengan media pembacaan puisi?

6. Perlukah kita meneladani sikap-sikap pahlawan? Mengapa? 
7. Sebagai pelajar bagaimana seharusnya kita meneladani sifat-sifat pahlawan? Beri contoh!

8. Apakah puisi kepahlawanan dapat memberikan inspirasi bagi kamu sebagai generasi muda? Jelaskan

9. Bagaimanakah pendapatmu tentang"pahlawan"? Bagaimana cara kamu menghargainya?

10. Menurutmu bagaimana sikap para pemuda sekarang terhadap rasa kebangsaan dan kepahlawanan? Mengapa hal tersebut dapat terjadi?

Daftar pertanyaan tersebut bersifat terbuka untuk jawaban siswa, dengan maksud siswa dapat menjelaskan atau memberikan pandangannya secara bebas, tidak tertekan atau terpaksa menjawab yang baik-baik saja, namun diharapkan siswa mengemukaan apa yang hendak disampaikan sesuai dengan hati nuraninya masing-masing.

Siklus IV yang diakhiri dengan tindakan ke-7 telah dapat memberikan bukti telah tercapainya semua tahap proses penanaman nilai, baik tahap transfer nilai yang ditandai dengan pengetahuan siswa tentang nilai-nilai kesejarahan dalam puisi kepahlawanan yang telah mereka bacakan, tahap transaksi nilai ditandai dengan pemahaman mereka akan nilainilai yang terkandung dalam puisi yang mereka analisis dengan argumentasi yang dikembangkan melalui deskripsi tentaqng puisi kepahlawanan, dan juga tahap trans-internalisasi yang ditunjukkan oleh para siswa melalui sikap, penjiwaaan, ungkapan perasaan, serta contoh aplikasi nilai yang ada pada puisi tersebut dikaitkan dengan kehidupan masa kini.

Dengan demikian, peneliti dan mitra/observer merasa bahwa penelitian tindakan kelas yang dilaksanakan kali ini telah memberikan kepuasan dan telah samapai pada titik saturasi, sehingga tindakan ke-7 pada siklus IV ini merupakan tindakan yang terakhir dalam PTK ini.

\section{PENUTUP}

\section{Simpulan}

Penanaman nilai-nilai kesejarahan sangat penting dilakukan pada para siswa, karena esensi pembelajaran sejarah bukan hanya memberikan pengetahuan semata bagi siswa tetapi yang lebih penting adalah bagaimana para siswa menjadikan sejarah sebagai pedoman dalam menghadapi masa kini dan masa yang akan datang sebagai bangsa Indonesia. Ini berarti bahwa nilai-nilai sejarah perlu menjadi watak kepribadian siswa dalam kehidupan.

Menanamkan nilai atau internalisasi nilai kesejarahan dalam pembelajaran sejarah, dapat dilakukan oleh guru sejarah dengan mengaplikasikan pembelajaran melalui pembacaan puisi kepahlawanan yang dihubungkan dengan pokok-pokok bahasan materi pelajaran sejarah. Proses pembelajaran melalui pembacaan puisi kepahlawanan ini dapat membangkitkan rasa nasionalisme dan pembentukan waktak dan kepribadian siswa, karena secara emosional para siswa akan mengeksplor sikap dan pandangan serta peniliainya terhadap perjuangan para pahlawan bangsa yang berdampak kepada pembentukan kepribadian sebagai generasi penerus yang harus berjuang meneruskan perjuangan para pahlawan dalam kontek dunianya sekarang.

Pembelajaran sejarah dengan menyajikan pembacaan puisi kepahlawanan untuk menanmkan nilai-nilai kesejarahan ini merupakan sebuah inovasi dalam pembelajaran sejarah, karena pembelajaran sejarah tidak hanya melulu disampaikan melalui ceramah yang dapat menimbulkan kebosanan dan menyebabkan siswa tidak berminat mempelajari sejarah.

\section{Rekomendasi}

1. Untuk Guru

a. Guru harus mampu mengembangkan pembelajaran sejarah yang inovatif dengan pembacaan puisi kepahlawanan untuk :

1) Menanamkan nilai-nilai kepahlawanan pada diri siswa sebagai generasi penerus perjuangan bagi kemajuan bangsanya

2) Memberikan pengetahuan bagi siswa akan pentingnya nilai-nilai dalam sejarah

3) Membangun kesadaran kebangsaan pada diri siswa

b. Menumbuhkan dan menanamkan sikap dan nilai kepahlawanan pada siswa untuk diaplikasikan dalam kehidupan seharihari

c. Guru sejarah harus kreatif dan inovatif dalam mengembangkan pembelajaran dan mengemas materi pelajaran sejarah, sesuai dengan tanggung jawabnya sebagai 
guru profesional dan sebagai pengembang kurikulum.

d. Guru harus memberi kesempatan pada siswa untuk melakukan inkuiri dalam pembelajaran sejarah untuk mengembangkan kemampuan merekonstruksi pengetahuannya secara mandiri.

e. Dengan upaya di atas guru akan mampu menanamkan nilai-nilai kesejarahan pada diri siswa menjadi watak atau karakter dan kepribadian siswa.

2. Untuk Sekolah

a. Sekolah memberikan ruang bagi guru sejarah berkreasi mengembangkan pembelajaran dengan berbagai model termasuk menjadikan puisi kepahlawanan sebagai cara atau metode guru dalam menyampaikan materi pelajaran sejarah, guna menanamkan nilai kesejarahan pada siswa dan menjadikannhya sebagai bagian pada muatan lokal dalam kurikulum pendidikan sejarah di sekolah.

b. Sekolah selalu memberikan motivasi kepada guru untuk berinovasi dalam melaksanakan tugas profesionalnya

c. Sekolah harus memberikan kesempatan pada guru untuk mengoptimalkan fungsinya sebagai pengembang kurikulum di sekolah.

d. Sekolah harus memberikan dukungan atas kreativitas guru baik moral maupun material.

e. Sekolah mengadakan upaya meningkatkan kemampuan pedagogik, profesional , dan kemampuan sosial guru dengan mengikutsertakan guru dalam berbagai kegiatan pendidikan dan latihan, baik di tingkat sekolah, MGMP, seminar nasional maupun internasional, maupun melalui pendidikan formal ke jenjang yang lebih tinggi.

\section{DAFTAR PUSTAKA}

Alwasilah, C, 2009, Pokoknya Kualitatif, Pustaka Jaya, Jakarta

Budiningsih, C, 2005, Belajar dan Pembelajaran, Rineka Cipta, Jakarta

Creswel, JW, 2010, Research Design Pendekatan Kualitatif, Kuantitatif, dan Mixed, Pustaka Pelajar, Yogyakarta,

Dahar, RW, 1996, Teori-Teori Belajar, Erlangga, Jakarta
Kabul Budiyono, (2007). Nilai-nilai Kepribadian dan Kejuangan Bangsa Indonesia, Bandung : Alfabeta.

Mulyana, Rohmat, 2004, Mengartikulasikan Pendidikan Nilai, Alfabeta, Bandung

Sanjaya, 2010, Penelitian Tindakan Kelas, Prenada, Jakarta

Supardan, D, 2009, Pengantar Ilmu Sosial Sebuah Kajian Pendekatan Struktural, Bumi Aksara, Jakarta

Supriatna, Nana, 2007, Konstruksi Pembelajaran Sejarah Kritis, Historia Utama Press, Bandung

Syah, M, 1995, Psikologi Pendidikan Suatu Pendekatan Baru, Remaja Rosdakarya, Bandung

Syaodih, N, 2010, Metode Penelitian Pendidikan, PT Remaja Rosdakarya, Bandung

Wiriaatmadja, R, 2008, Metode Penelitian Tindakan Kelas, PT Remaja Rosdakarya, Bandung

Sumber Internet

Artikelsiana.com, 2015, Pengertian Puisi, Ciri, Jenis-Jenis, Unsur \& Struktur Puisi Secara Umum, Oktober 2015, [Online], Tersedia :

http://www.artikelsiana.com/2015/10/pen gertian- puisi- ciri- jenis-jenisunsur.html\# , [diunduh 20 Mei 2016

Calie Priboemi Blog, 2014, Internalisasi Nilai, 18 September 2014, [Online],

Tersedia

http://zangpriboemi.blogspot.co.id/2014/ 09/internalisasi-nilai.html

[diunduh 6 Mei 2016]

Faesol, Tommy, 2008, ANALISIS PUISI KARAWANG-BEKASI KARYA CHAIRIL ANWAR ANALISIS SASTRA DALAM PUISI KARAWANG - BEKASI Karya Chairil Anwar, April 2014, [Online]

Tersedia http://tommyfae.blogspot.co.id/2014/04/a nalisis-puisi-karawang-bekasi-karya.htm

Fauzul Maustaqim, 2015, Fauzul, Makalah Strategi Internalisasi Nilai, Nopember 2015, [Online], Tersedia: http://www.fauzulmustaqim.com/2015/1 1/ makalah- strategi- internalisasinilai.html [diunduh 6 Mei 2016]

Hapsari, 2015, NILAI KEPAHLAWANAN DALAM PEMBENTUKAN 
KARAKTER BANGSA, 10 Mei 2015 , [Online], Tersedia:

https://hapsarisasi.wordpress.com/2015/0 5/10/nilai-kepahlawanan-dalam-

pembentukan-karakter-bangsa/ [diunduh 6 Pebruari 2016]

Lukas Gentara, Kumpulan Puisi Hari Kartini 21 April 2016, April 14, 2016 [online]

Tersedia:

http://www.gen22.net/2013/04/kumpulan -puisi-hari-kartini.html [20 April 2016]

Muh Darlis, Andi (Kasipamsutmat Dispamsanau), 2015, Harian Nasional, Internalisasi Nilai Kepahlawanan untuk Bangsa, 10 November 2015, [Online] Tersedia http://www.harnas.co/2015/11/10/interna lisasi-nilai-kepahlawanan-untuk-bangsa [diunduh 6 Mei 2016]

Mulyana, A, 2009, Mengembangkan Keterampilan Penelitian dalam Pembelajaran Sejarah, Makalah disampaikan pada Workshop Kesejarahan Mengembangkan Budaya Demoktasi Melalui Pembelajaran Sejarah, yang dimiliki oleh masyarakat kita. [Online].

Tersedia:http://file.upi.edu/Direktori/FPI PS/JUR._PEND._SEJARAH/196608081 991031-

AGUS_MULYANA/Makalah_Jarahnitra 09.pdf [15 Mei 2011]

Rifqi, Zuhardi, 2015, Materi Antropologi Kelas X: Internalisasi Nilai-Nilai Budaya Dalam Pembentukkan Kepribadian Dan Karakter, 16 Desember 2015, [Online] Tersedia:

http://blog.unnes.ac.id/zuhadrifqi2/2015/ 12/16/materi-antropologi-kelas- $X-$ internalisasi-nilai-nilai-budaya-dalampembentukkan-kepribadian-dan-karakter/ [diunduh 6 Mei 2016]

Sardiman AM, Pembelajaran Sejarah dan Nilainilai Kepahlawanan, [Online] Tersedia : https://www.google.co.id/?gws_rd=ssl\#q =nilai+nilai+ KEPAHLAWanan [diunduh 6 Pebruari 2016]

Sutopo H.B. 2002. Metode Penelitian Kualitatif. Surakarta: Universitas Sebelas Maret. diselenggarakan oleh Direktorat Nilai Sejarah Direktorat Jenderal Sejarah dan Purbakala Departemen Kebudayaan Pariwisata, Denpasar, 16-20 Juni 2009. [Onine]. Tersedia: http://lib.uin- malang.ac.id/thesis/chapter_iii/07110155

-abdul-choliq.ps [15 Januari 2012]

Wedhaswary, Inggried Dwi, KOMPAS.com, 2011 Pendidikan Karakter Sekolah Harus Tanamkan Nilai Kepahlawanan, 10 November 2011, [Online]

Wikipedia bahasa Indonesia, ensiklopedia bebas, Puisi, [Online], Tersedia : https://id.wikipedia.org/wiki/Puisi, [diunduh 6 Pebruari 2016]

Wikipedia bahasa Indonesia, ensiklopedia bebas Nilai, [Online], Tersedia : https://id.wikipedia.org/wiki/Nilai, [diunduh 5 Mei 2016] 